\title{
A Acessibilidade de Pessoas com Daltonismo: A Construção de um Protótipo de AVA Inclusivo
}

\author{
The Accessibility People with Color Blindness: \\ Construction of a Prototype AVA Inclusive
}

RITA DE CASSIA MIRANDA DA COSTA Universidade do Oeste Paulista (UNOESTE)

ADRI ANA APARECIDA DE LIMA TERÇARIOL Universidade Nove de Julho (UNINOVE)

FERNANDA SUTKUS DE OLIVEIRA MELLO Universidade do Oeste Paulista (UNOESTE)

SIDINEI DE OLIVEIRA SOUSA Universidade do Oeste Paulista (UNOESTE)

\author{
ELISANGELA APARECIDA BULLA IKESHOJ I \\ Instituto Federal de Educação, Ciência e Tecnologia de São Paulo (IFSP)/Câmpus Birigui
}

\begin{abstract}
Resumo: O presente estudo teve como finalidade desenvolver um protótipo de módulo digital que pudesse melhorar e/ou adequar o acesso de pessoas com daltonismo ao Ambiente Virtual de Aprendizagem (AVA) "Aprender Unoeste". A pesquisa assumiu um caráter qualitativo. Os principais resultados evidenciam caminhos que podem ser utilizados para que ambientes virtuais adotados em atividades presenciais e/ou a distancia por instituições de ensino superior possam ser enriquecidos com recursos que propiciem o pleno acesso de todos, em especial, das pessoas com daltonismo. Considerar determinadas especificidades para se promover o acesso efetivo de pessoas com daltonismo aos AVA, propiciando condições mais eficientes de leitura e visualização das informações gerais, incluindo dos materiais didáticos disponíveis.
\end{abstract}

Palavras-chave: Acessibilidade. Inclusão. Daltonismo. Ambiente Virtual de Aprendizagem.

Abstract: The present study aimed to develop a prototype digital module that could improve and / or adapt the access of people with color blindness to the Virtual Learning Environment (VLE) "Learning Unwest". The research assumed a qualitative character. The main results highlight the ways in which virtual environments adopted in face-to-face and / or distance learning activities by higher education institutions can be enriched with resources that provide full access for all, especially those with color blindness. Consider certain specificities to promote the effective access of people with color blindness to VLE, providing more efficient conditions for reading and visualizing the general information, including the available didactic material.

Keywords: Accessibility. Inclusion. Color Blindness. Virtual Learning Environment. 


\section{I ntrodução}

A Educação a Distância $(\mathrm{EaD})$, caracteriza-se pela educação mediada por suportes técnicos de comunicação entre pessoas em tempo e lugares diferentes, conforme pontua o decreto $\mathrm{n}^{\circ}$ 5.622, de 19 de dezembro de 2005:

[...] caracteriza-se a educação a distância como modalidade educacional na qual a mediação didático-pedagógica nos processos de ensino e aprendizagem ocorre com a utilização de meios e tecnologias de informação e comunicação, com estudantes e professores desenvolvendo atividades educativas em lugares ou tempos diversos. (BRASIL, 2005, p. 1).

Nos dias atuais inúmeros são os meios e as Tecnologias de Informação e Comunicação (TIC) articuladas à viabilização da EaD. A oferta de cursos online, por exemplo, coexiste com cursos ofertados por correspondência. Isso sinaliza que as instituições estão buscando diversas possibilidades de interação em escala mundial e a total queda das barreiras de tempo e espaço. Isso leva a EaD a um novo patamar, no qual modelos pedagógicos precisam ser repensados para os novos processos cognitivos das pessoas inseridas no ciberespaço. O ciberespaço é entendido aqui como "espaço de comunicação aberto pela intercomunicação mundial dos computadores e das memórias dos computadores" (LÉVY, 1999, p. 92).

O desenvolvimento desses espaços interativos com fins educacionais e as comunidades de e-learning propiciaram o surgimento de Ambientes Virtuais de Aprendizagem (AVA), definidos por Behar et al. (2008, p. 29) como:

[...] espaço na internet formado pelos sujeitos e suas interações e formas de
comunicação que se estabelecem por meio de uma plataforma, tendo como
foco principal a aprendizagem [...]. Dentre as funcionalidades da plataforma
podem ser citadas as de comunicação síncrona e assíncrona, entre elas o bate-
papo (ou chat), MSN, fórum de discussão, diários de bordo, base de dados,
funcionalidades que dão suporte ao trabalho em grupo, publicações de
arquivos.

São novas formas de apreender conteúdos e construir novos conhecimentos, o que demanda a necessidade de reformulação dos aspectos pedagógicos, bem como das interfaces dos ambientes virtuais nos quais esses cursos são desenvolvidos. Somente dessa maneira, será possível ampliar as oportunidades de espaços educativos acessíveis a todos, independente de suas condições geográficas, sociais, intelectuais, físicas, entre outras.

Para tanto, torna-se importante usufruir ao máximo das potencialidades das TIC, suprindo as necessidades de um mundo não só mais globalizado, como também inclusivo. Além disso, a implementação de um curso a distância implica o planejamento de uma arquitetura pedagógica que contemple: aspectos organizacionais (objetivo do projeto, local, duração, atribuição de tarefas etc), o conteúdo (materiais utilizados para propiciar a "apropriação do conhecimento"), aspectos metodológicos e aspectos tecnológicos (ambientes virtuais de aprendizagem e suas ferramentas), conforme pontua Behar et al. (2008).

A partir disso, o conteúdo, enquanto "qualquer tipo de material e/ou elemento(s) utilizado(s) com a finalidade de apropriação do conhecimento" (BEHAR et al., 2008, p. 27) 
precisa ser pensado e adequado para a modalidade a distância, bem como dentro dos preceitos da educação inclusiva e das questões legais relativas à acessibilidade, de modo que possa cumprir seu propósito educativo. Ao ser disponibilizado para alunos com deficiência visual, por exemplo, o conteúdo precisa estar em mídia acessível, como o som e o texto, em ambientes igualmente acessíveis.

É importante que um ambiente que abarque as necessidades das pessoas se adeque às dimensões da acessibilidade e à premissa do desenho universal, conceito criado pelo americano Ron Mace. Ao tornar-se signatário da Convenção sobre Direito das Pessoas com Deficiência, o Brasil corrobora da seguinte definição de desenho universal:

\begin{abstract}
"Desenho universal" significa a concepção de produtos, ambientes, programas e serviços a serem usados, na maior medida possível, por todas as pessoas sem necessidade de adaptação ou projeto específico. O "desenho universal" não excluirá as ajudas técnicas para grupos específicos de pessoas com deficiência, quando necessárias. (BRASIL, 2009, p. 3).
\end{abstract}

Enquanto o desenho universal não se torna prática comum são necessários ajustes para atender aos quesitos de acessibilidade, em especial à dimensão comunicacional, objeto de estudo deste trabalho. A riqueza de ferramentas dos AVA evoca interatividade. No entanto, o entusiasmo oriundo dos recursos interativos finda quando constatado que muitos usuários não conseguem sequer acessá-los, muito menos utilizá-los para interagir com outras pessoas.

No tocante às pessoas com deficiência visual, o problema não fica restrito à navegação pela interface, pois uma vez tendo acesso à ferramenta, geralmente, ainda faltam informações sobre os conteúdos visuais, ou seja, falta acessibilidade. Sonza, Conforto e Santarosa (2008, p. 135) propõem a seguinte definição de acessibilidade à web:

Entende-se por acessibilidade à rede a possibilidade de qualquer indivíduo, utilizando qualquer tipo de tecnologia de navegação (navegadores gráficos, textuais, especiais para cegos ou para sistemas de computação móvel), poder visitar qualquer site e obter um total e completo entendimento da informação contida nele, além de ter total e completa habilidade de interação.

Infere-se da definição supracitada que a criação de páginas na web específicas para pessoas com deficiência visual, como alternativa aos conteúdos de um site qualquer, não é uma proposta de acessibilidade, pois os usuários continuarão impossibilitados de acessar, interagir ou compreender a página original. Os AVA e os demais web sites utilizam-se dos mesmos suportes tecnológicos, diferenciando-se, essencialmente, de acordo com a proposta e ferramentas disponíveis (MACHADO JÚNIOR, 1998 apud BESSANI et al., 2010). Portanto, a discussão dos quesitos de acessibilidade em AVA, norteia-se pelas mesmas diretrizes recomendadas para qualquer página da web.

Nesse sentido, a fim de orientar desenvolvedores quanto aos recursos necessários para prover acessibilidade, alguns documentos foram publicados. Em 1999, a World Wide Web Consortium - mais conhecida como W3C, divulgou as Diretrizes para Acessibilidade do Conteúdo Web 1.0 (em inglês, Web Contente Acessibility Guidelines - WCAG 1.0). Esse documento é tido como o mais completo e relevante documento já criado, não tendo sido 
superado nem pelo WCAG versão 2.0, produzido pela mesma organização (SONZA; CONFORTO; SANTAROSA, 2008). Outros autores, como Bessani et al. (2010), passaram a adotar o WCAG 2.0. No Brasil, foi criado o Manual de Acessibilidade do Governo Eletrônico (eMAC), em 2005.

As diretrizes, além de orientações para o desenvolvimento e análise dos ambientes virtuais alocados na web, contribuem para a aplicação de outros dois conceitos, introduzidos aqui por Sonza, Conforto e Santarosa (2008): usabilidade e comunicabilidade, aplicados à web.

No que se refere à usabilidade, compreende-se que indica a navegação confortável dos web sites. Segundo Kulpa, Teixeira e Silva (2010 apud NOBREGA, 2011, p. 16), "uma interface com qualidade de usabilidade está na sua adequação às necessidades do usuário, sem que o mesmo tenha que se adaptar ao sistema através da interface". De acordo com Sonza, Conforto e Santarosa (2008), os pontos essenciais para assegurar a usabilidade são: as cores, o redimensionamento, o contraste, os atalhos, o contexto, orientação e auxílio para navegação.

Quanto à comunicabilidade, trata-se da qualidade das interfaces compreendidas pelos seus usuários, do modo desejado pelos seus projetistas, pois a compreensão da lógica de interação, por parte do usuário facilitará seu relacionamento com o sistema (PRATES; BARBOSA, 2016). Aplicada à web, entende-se que a comunicabilidade reflete sobre a clareza dos elementos visuais como ilustrações, fotos e botões, por exemplo (SONZA; CONFORTO; SANTAROSA, 2008).

Diante desse cenário, no que se refere ao acesso de pessoas com deficiência visual, em especial, o daltonismo, aos ambientes virtuais de aprendizagem, torna-se de extrema relevância que se considere suas necessidades especiais e se promova a concepção e criação desses espaços educativos, respeitando o que as diretrizes da área sinalizam quanto à usabilidade e à comunicabilidade.

Nesse cenário, a presente pesquisa apresentou como principal finalidade propor o desenvolvimento de um protótipo de módulo que melhore e/ou adeque o acesso de pessoas com daltonismo aos ambientes virtuais de aprendizagem, favorecendo assim, a inclusão dessas pessoas a cursos oferecidos na modalidade a distância, propiciando condições mais eficientes de leitura das informações gerais e dos materiais didáticos, disponíveis nesses ambientes.

A pesquisa assumiu um caráter qualitativo, uma vez que a proposta de investigação focou o estudo a respeito da acessibilidade de pessoas com daltonismo aos ambientes virtuais de aprendizagem, adotando como plataforma de referência o Aprender Unoeste, ambiente virtual de aprendizagem desenvolvido pela Universidade do Oeste Paulista - Unoeste - Presidente Prudente/SP.

Sendo assim, este artigo tem como objetivo discutir os principais eixos temáticos que circundam a pesquisa realizada, bem como apresentar o protótipo criado a partir dos estudos desenvolvidos, destacando os avanços obtidos e as perspectivas para a sua continuidade.

\section{Daltonismo e suas especificidades}

É preciso compreender que um grande número de pessoas em todo o mundo tem algum tipo de deficiência, física, mental ou sensorial, que limita sua habilidade para as atividades 
diárias. Não existem dados exatos sobre a quantidade de pessoas nesse contexto, apenas percentuais estimados. No Brasil, tais percentuais revelam que quase ${ }^{1 / 4}$ da população (23\%) possui algum tipo de deficiência, o que significa cerca de 45,6 milhões de pessoas (COLOR BLIND AWARENESS, 2014).

Pesquisas realizadas pelo Color Blind Awareness (2014) indicam que o daltonismo afeta aproximadamente 1 em cada 12 homens (8\%) e 1 em cada 200 mulheres (0,005\%) no mundo. Na Grã-Bretanha, isso significa que existem cerca de 2,7 milhões de pessoas daltônicas (cerca de $4,5 \%$ de toda a população), a maioria dos quais são do sexo masculino.

O daltonismo tem causa genética. Está relacionado a um gene recessivo localizado no cromossoma X e ocorre com maior frequência entre os homens. A mulher pode ter visão normal, mas ser portadora do gene recessivo e passar aos filhos. Existem diferentes causas de daltonismo. Para a grande maioria das pessoas com deficiência de visão de cores, a condição é genética e foi herdada de sua mãe, embora algumas pessoas fiquem cegas para cor como resultado de outras doenças, como diabetes e esclerose múltipla ou ainda adquirem a condição ao longo do tempo devido ao processo de envelhecimento, medicação, entre outros (COLOR BLIND AWARENESS, 2014).

O daltonismo não é considerado um distúrbio de grande dificuldade, não ao ponto de atrair a atenção para que sejam realizados ajustes e melhorias nos elementos do cotidiano em que a distinção de cores é fundamental.

As pessoas com Monocromacia enxergam em tons pastel ou acinzentado quando possuem $100 \%$ desse distúrbio, se ocorrer em menor porcentagem, confundem verde e vermelho ou enxergam em tons mais claros e é nestes casos que ocorre a confusão de cores semelhantes. 0 daltonismo não tem cura e este é um grande incentivo para a preocupação com a acessibilidade para as pessoas com este distúrbio.

I magine-se nesta situação: você está em um restaurante, bar ou qualquer ambiente do gênero, e necessite ir ao banheiro, esta é uma situação comum, corriqueira do dia a dia, algo como andar, não pensamos, apenas seguimos o rumo do nossa intenção já determinada. Porém, ao chegarmos ao banheiro, nos deparamos com as opções apresentadas na Figura 1.

Figura 1 - Visão da pessoa com 100\% de daltonismo.

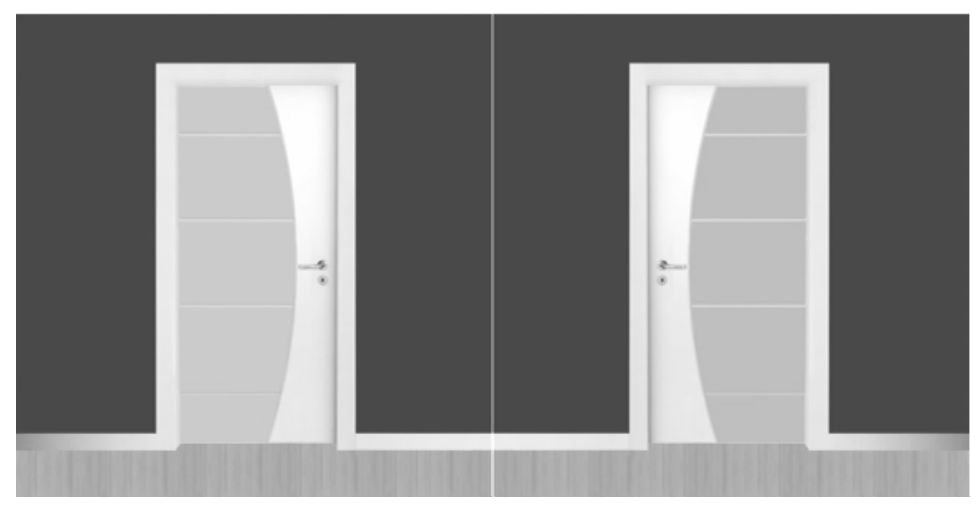

Fonte: Elaborado pelos autores. 
Qual seria sua escolha? Esse pequeno desconforto e confusão ao qual nos submetemos nessa situação proposta é algo que as pessoas com esse distúrbio enfrentam todos os dias. Esse, simples ato para alguns, causa constrangimento.

É preciso ver além do tamanho da dificuldade, pois conforme apresentado, na situação acima, pode ocorrer "apenas" um desconforto, porém se for o caso de uma prova de concurso público em que se exija a visualização de cores, a leitura de um mapa ou gráfico, será uma desvantagem. E se a pessoa nessa situação se deparar com a necessidade de desenvolver uma atividade em um ambiente virtual de aprendizagem? É preciso antes de tudo, compreender que não é somente um simples desconforto, é questão de igualdade, adaptar para tornar justo ou ao menos, igualitárias as oportunidades.

\section{Ambientes virtuais de aprendizagem e acessibilidade}

Cerca de $15,8 \%$ dos alunos matriculados em faculdades em todo o país optaram por cursos de graduação a distância. Em torno de 1,15 milhão de estudantes, segundo o censo da educação superior divulgado pelo Ministério da Educação em 2014 (BRASI L, 2014).

A grande procura por esta modalidade estimulou também a preocupação com a acessibilidade nos ambientes virtuais de aprendizagem. De acordo com o pensamento de Nóbrega (2011) a educação a distância já é uma ação inclusiva, por oportunizar processos formativos àqueles que necessitam de flexibilidade de tempo e/ou distância. É nesse contexto que emerge a preocupação com a acessibilidade de pessoas com daltonismo aos ambientes virtuais de aprendizagem.

Entende-se por acessibilidade, de acordo com a definição proposta pelo Decreto Federal noㅡ 5.296/2004, artigo $8^{\circ}$ :

I - Acessibilidade: condição para utilização, com segurança e autonomia, total ou assistida, dos espaços, mobiliários e equipamentos urbanos, das edificações, dos serviços de transporte e dos dispositivos, sistemas e meios de comunicação e informação, por pessoa portadora de deficiência ou com mobilidade reduzida. (BRASIL, 2004, grifo nosso).

Segundo Sassaki (2005), existem seis dimensões da acessibilidade necessárias para a criação de ambientes educacionais inclusivos, sendo elas: a arquitetônica, a metodológica, a instrumental, a pragmática, a atitudinal e a comunicacional. Esta última refere-se também à acessibilidade digital. Esse autor apresentou uma sucinta definição de cada dimensão a qual segue:

- Acessibilidade arquitetônica: refere-se ao ambiente físico, o qual é previsto que não haja limitações do espaço tanto nas locações internas quanto externas da escola, incluso também o transporte por ela ofertado.

- Acessibilidade metodológica: neste caso trata dos métodos e técnicas de estudo de ação comunitária e de educação dos filhos, no qual é preciso sair dos padrões e buscar formas atualizadas e mais interativas. 
- Acessibilidade instrumental: refere-se à preocupação com os instrumentos e utensílios utilizados nas atividades da vida diária, no estudo, no lazer, esporte e recreação, são dispositivos que atendam às barreiras sensoriais, físicas e mentais entre outras.

- Acessibilidade pragmática: diz respeito às restrições ou limitações definidas por políticas públicas, por meio de leis e similares ou mesmo em regulamentos e/ou em normas em geral.

- Acessibilidade atitudinal: aborda a divulgação por mídia e/ou movimentos de conscientização e sensibilização de todos e da convivência na diversidade humana, com isso busca-se superar paradigmas, preconceitos, estereótipos e principalmente as discriminações.

- Acessibilidade comunicacional: versa sobre a não limitação da comunicação interpessoal, na escrita e na comunicação virtual. Essa última pode ser associada à acessibilidade digital, abordada no presente artigo.

A preocupação com a acessibilidade nos ambientes virtuais está presente em todos os textos selecionados para embasar o pensamento aqui abordado. Behar et al. (2008, p. 4) defende que “o conteúdo das páginas e as ferramentas devem ser acessíveis porque muitas pessoas podem, total ou parcialmente, não ver, ouvir, mover ou mesmo processar com dificuldade algum tipo de informação."

Porém, é preciso observar que, há uma crescente preocupação com relação à acessibilidade, de um modo geral, nas várias esferas da sociedade. Essa preocupação se manifesta na forma de ações reguladas por lei, tais como: a criação de rampas de acesso para cadeirante, elaboração de provas de concursos/vestibular específicas a cada deficiência, entre tantos outros exemplos. Todavia, apesar desse fato, que representa um salto positivo para a qualidade de vida das pessoas com necessidades, a acessibilidade no meio virtual não possui igual foco até o presente momento.

Nesse sentido, Torres, Mazzoni e Alves (2002, p. 85), citam a falta de mecanismos intergovenamentais que possam promover a acessibilidade dos conteúdos encontrados na internet e ainda ressaltam: "A não-observância da acessibilidade no espaço digital, pelos autores dos materiais disponibilizados, nessa forma pode ser considerada como uma discriminação feita a milhares de usuários".

Após a discussão aqui apresentada a respeito do daltonismo e suas especificidades e compreendermos as dimensões da acessibilidade, incluindo a comunicacional que se associa aos ambientes virtuais de aprendizagem, apresentar-se-á o percurso metodológico adotado para o desenvolvimento deste estudo e construção do protótipo acessível ao usuário daltônico, adotando como parâmetro o AVA Aprender Unoeste.

\section{Percurso metodológico}

A construção deste artigo é resultado de estudos desenvolvidos a partir de um trabalho de revisão da literatura, bem como da elaboração de uma proposta que prevê a possibilidade de construção de recursos de acessibilidade, considerando as necessidades especiais de um daltônico ao acessar um AVA, especificamente, o ambiente virtual Aprender Unoeste.

A revisão bibliográfica possibilitou aos pesquisadores o contato com estudos já realizados na área de "Acessibilidade e Educação a Distância", assim como a identificação de suas ideias 
principais. Essa aproximação com o tema ocorreu a partir da análise de publicações disponíveis nas seguintes bases de dados: Capes, Google Acadêmico e Scielo.

Esses acervos foram selecionados devido ao fato de estarem disponíveis, ou seja, com acesso aberto e online aos usuários, tornando possível a análise de trabalhos completos publicados em periódicos brasileiros. Por meio desse procedimento, iniciou-se a busca e levantamento de publicações científicas, produzidas no Brasil, entre 2000 e 2016, que abordassem temáticas próximas desta investigação, tais como: Inclusão; Daltonismo; Educação a Distância; Ambiente Virtual de Aprendizagem.

Nesse sentido, os descritores utilizados foram os seguintes: "Acessibilidade", "Ambiente Virtual de Aprendizagem" e "Daltonismo". A busca foi realizada, de forma individual, com cada descritor, e depois utilizando a junção entre eles. O Quadro 1, apresentado a seguir, demonstra o levantamento realizado.

QUADRO 1 - Busca inicial dos artigos científicos.

\begin{tabular}{|l|c|c|}
\hline Base de pesquisa & Artigos disponibilizados & Artigos selecionados \\
\hline Capes & 70 & 2 \\
\hline Google Acadêmico & 5629 & 7 \\
\hline Scielo & 378 & 15 \\
\hline Total & 6077 & \\
\hline
\end{tabular}

Fonte: Elaborado pelos autores.

Após selecionar os artigos que condiziam com a temática, realizou-se a leitura de todos os resumos, o objetivo era identificar a abordagem de cada artigo para que fosse possível demarcar qual texto obteria melhor aproveitamento para o desenrolar dos tópicos/subtítulos distribuídos ao longo deste estudo. Enfatiza-se aqui então que os artigos selecionados, a partir do levantamento bibliográfico realizado, foram utilizados para fundamentar as ideias sistematizadas pelos pesquisadores neste artigo.

Além dos procedimentos adotados para o encaminhamento da revisão sistemática da literatura, vale destacar ainda os principais encaminhamentos, ou seja, as etapas gerais contempladas para a criação do protótipo, apresentado como produto nesta pesquisa:

\subsection{Etapa 1 - Levantamento e estudo dos tipos de daltonismo}

Por meio dessa etapa foi possível identificar a existência de vários tipos de daltonismo, compreendendo suas características principais, a saber:

Tricromacia: tipo de visão de cores normal, usa todos os três tipos de cones luz corretamente, e é conhecido como tricromacia. Pessoas com visão normal das cores são conhecidas como tricomatas (COLOR BLIND AWARENESS, 2014). As diferentes condições anômalas são protanomalia, que é uma reduzida sensibilidade à luz vermelha, deuteranomalia 
que é uma reduzida sensibilidade à luz verde e é a forma mais comum de cegueira e cor tritanomalia que é uma reduzida sensibilidade à luz azul e é extremamente rara (COLOR BLIND AWARENESS, 2014).

Dicromacia: pessoas com visão Dicromatica têm apenas dois tipos de cones que são capazes de perceber a cor, ou seja, eles têm uma total ausência de função de um tipo de cone (COLOR BLIND AWARENESS, 2014). Pessoas que sofrem de protanopia são incapazes de perceber qualquer luz "vermelha", aqueles com deuteranopia são incapazes de perceber a luz "verde" e aqueles com tritanopia são incapazes de perceber a luz "azul" (COLOR BLIND AWARENESS, 2014).

Monocromacia (Acromatopsia): pessoas com visão monocromática enxergam seu mundo composto de diferentes tons de cinza que variam do preto ao branco, como se "assistissem" ao mundo por meio de uma velha televisão com um conjunto de tonalidade entre o preto e o branco. Acromatopsia é extremamente rara, ocorrendo apenas em cerca de 1 pessoa em 33.000 e seus sintomas podem tornar a vida muito difícil. Normalmente alguém com acromatopsia terá de usar óculos escuros dentro das condições normais de luz.

Enfim, compreendeu-se que daltonismo é um distúrbio da percepção visual caracterizado pelo não funcionamento dos cones oculares responsáveis por diferenciar todas ou algumas cores. Sua origem está, principalmente, relacionada à hereditariedade e sua incidência é em média vinte vezes mais comum em homens.

\subsection{Etapa 2 - Análise do “Aprender Unoeste”}

A análise do ambiente virtual de aprendizagem Aprender Unoeste foi realizada com o propósito de se verificar as cores desse AVA, adotado nesta pesquisa, para identificar quais poderiam prejudicar a visibilidade dos estudantes daltônicos.

\subsection{Etapa 3 - Escolha da melhor localização para inserir o recurso}

A partir da análise da plataforma Aprender Unoeste identificou-se que seria necessário acrescentar o botão "Acessibilidade", conforme apresentado na Figura 2. Nela seriam descritos os meios de acessibilidade fornecidos pela Unoeste, tanto no espaço físico, quanto no virtual. 

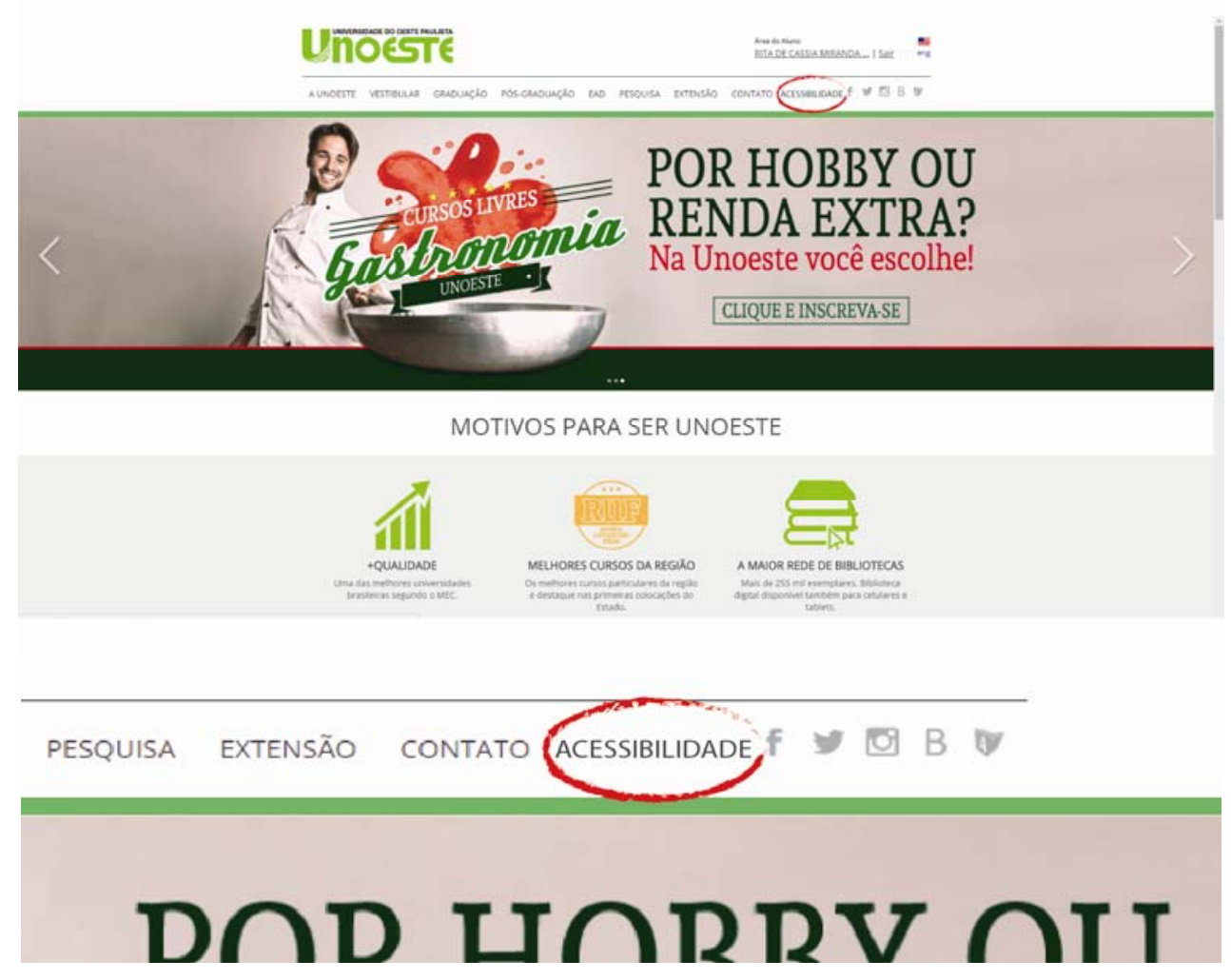

Fonte: Elaborado pelos autores.

Nesse ambiente verificou-se ainda a necessidade de, posteriormente, adicionar uma explicação do que é e como funciona a acessibilidade para daltonismo. Essa explicação poderá ser feita por meio de vídeo autoexplicativo, infográfico ou sequência de imagens, descrevendo os passos para ativar o ícone e como o ambiente ficará, de forma semelhante à explicação contida neste.

O estudante ainda terá a opção de escolher a forma de visualizar a legenda que mostra a escrita da cor, ao passar o mouse sobre a imagem, ou optar pela forma de ícone, no qual é apresentado o ícone correspondente a cor.

Essa ideia será apresentada a um programador junto ao setor de Tecnologia da Informação (TI) da Unoeste, para ser avaliada a possibilidade da aplicação desse modelo para todo o ambiente virtual Aprender Unoeste, ou se seria relevante a sua aplicação, focada apenas nos ambientes das atividades das disciplinas e cursos ofertados.

\subsection{Etapa 4 - Construção do protótipo}

A partir dos estudos realizados, foi construída uma proposta de protótipo adaptando o ambiente virtual de aprendizagem “Aprender Unoeste" para uma versão acessível aos usuários daltônicos.

Inicialmente, foi pensado na técnica de converter cores para daltônicos, por meio do tratamento e acentuação das tonalidades de cores em imagens, recolocando-as na web, 
contudo foi levado em consideração o pensamento de Gomes e Ribeiro (2012, p. 2), o qual segue: “não obstante o já elevado número de investimento nesta área, não existe ainda um sistema integrado que possibilite recoloração global das páginas web, sendo essa perspectiva constituiria uma notória melhoria na acessibilidade, para daltônicos."

Com isso, chegou-se a conclusão que este não é o objetivo, até porque já existem ferramentas para esta função, as quais podem ser aplicadas na imagem selecionada.

O intuito do protótipo desta pesquisa é fazer com que a informação apresentada pela cor fique evidente para o daltônico, ou seja, a intenção é deixar o conteúdo tão aparente quanto para uma pessoa que não possua este distúrbio. Antes de apresentá-lo, é preciso levantar de antemão duas variáveis encontradas em sua construção e conclusão, essas variáveis serão solucionadas ao término da apresentação, do projeto a seguir.

Essas variáveis implicam algumas limitações, as quais é preciso dedicar atenção. Com relação à primeira variável, o daltonismo interfere na distinção das cores de fotografias ou imagens, e mesmo que o daltônico consiga identificar variações de cores na imagem, é possível que ainda não enxergue o que a imagem representa, pois, nesse caso, as cores visualizadas podem ter tonalidades bastante semelhantes, resultando em confusão perceptiva por não enxergarem detalhes importantes para a total identificação das imagens. No que se refere à segunda variável, há casos em que alguns textos estão organizados dentro de caixas, nesses casos, é comum o texto ter uma determinada cor e a caixa (fundo do texto), possuir outra cor. Nessa situação, é possível que ocorra a mesma confusão citada na visualização da imagem pelo daltônico, porém essa confusão irá interferir na leitura do texto dentro da caixa.

Garcia et al. (2013, p. 2), apresenta tal preocupação e chama a atenção para a necessidade de estarmos atentos aos diferentes graus de daltonismo.

Para atender e proporcionar satisfação aos usuários é de vital importância que as interfaces sejam desenvolvidas de acordo com as necessidades de cada um e que gerem o menor desconforto possível, seja na disposição de ícones e botões, vocabulários impróprios ou na combinação das cores.

A partir desse entendimento, foi possível chegar a dois modelos de adaptação: Legenda em Escrita e Legenda ColorAdd, conforme apresenta-se a seguir.

\section{Legenda em escrita}

O primeiro modelo de adaptação, conforme mostra a Figura 3 e 4, consiste na apresentação para o daltônico do nome da cor, assim que ele passa o mouse sob qualquer elemento que tenha cor. O uso do mouse para essa finalidade é para promover a interface do daltônico quando ele estiver usando computadores, notebooks ou similares. No caso de dispositivos móveis, como, por exemplo, smartphones ou tabletes, a visualização do nome da cor será conseguida por meio do touch-screen sob a imagem ou palavra em questão. Para ambos os tipos de dispositivos, aparecerá para o daltônico o nome da cor de forma escrita. É importante ressaltar que o nome da cor atenderá a um contraste que possibilitará a correta identificação e leitura do texto com o nome da referida cor. 
Figura 3 - Modelo do Protótipo “Legenda em escrita” - Cor azul claro.

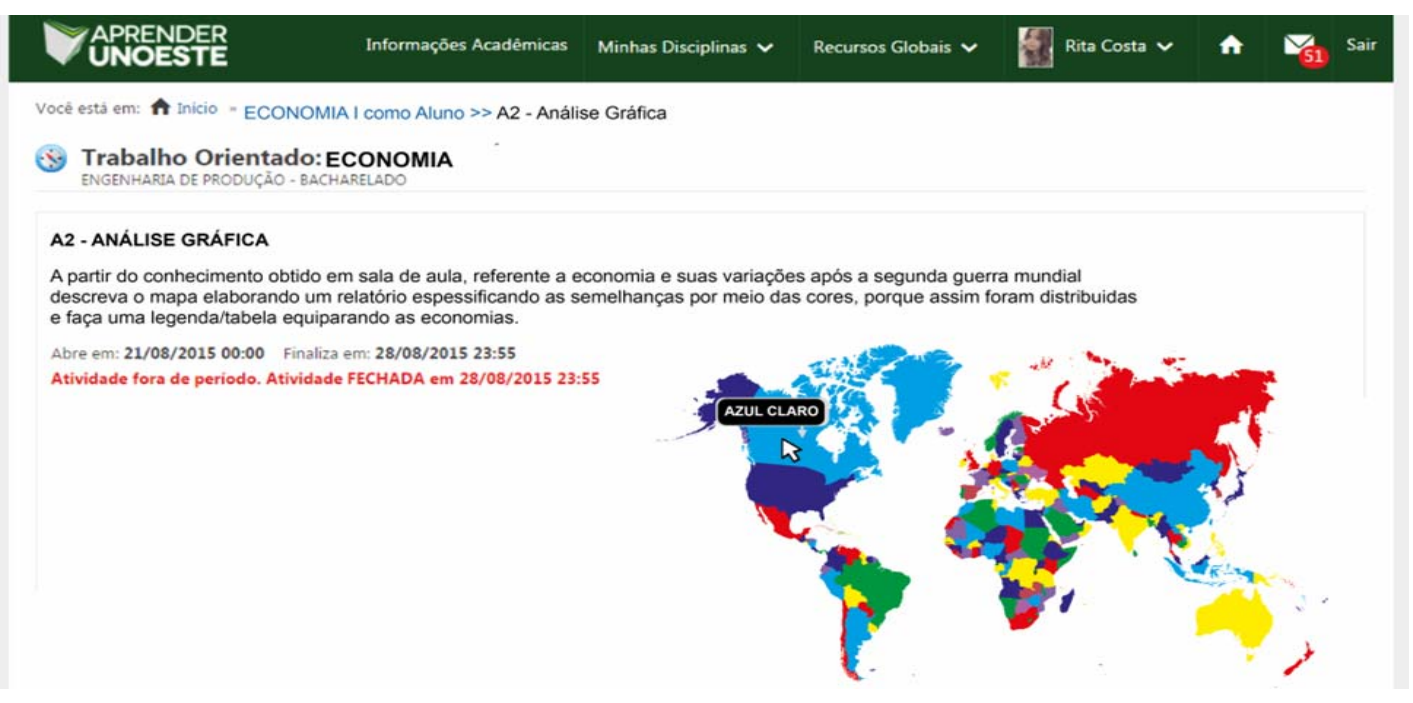

Fonte: Elaborado pelos autores.

Figura 4 - Modelo do Protótipo “Legenda em escrita” - Cor vermelho.

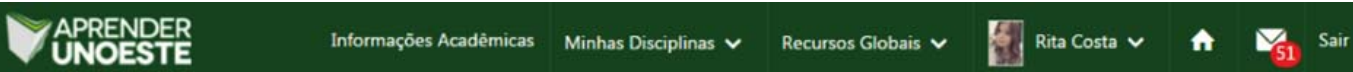

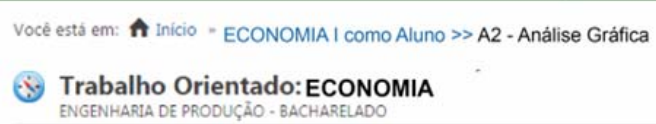

\section{A2 - ANÁLISE GRÁFICA}

A partir do conhecimento obtido em sala de aula, referente a economia e suas variaçōes após a segunda guerra mundial

descreva o mapa elaborando um relatório espessificando as semelhanças por meio das cores, porque assim foram distribuidas

e faça uma legenda/tabela equiparando as economias.

\section{Abre em: 21/08/2015 00:00 Finaliza em: 28/08/2015 23:55}

Atividade fora de periodo. Atividade FECHADA em 28/08/2015 23:55

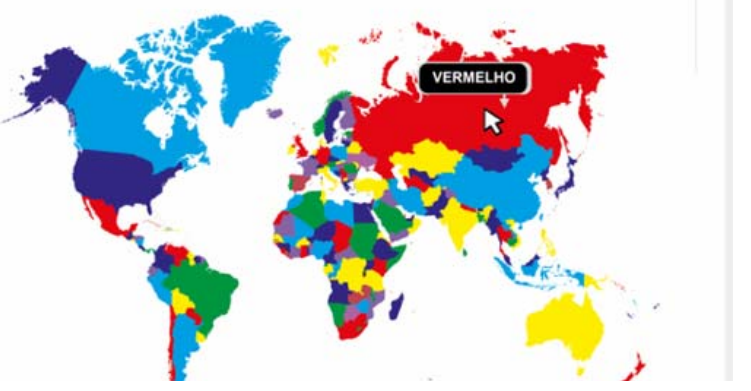

Fonte: Elaborado pelos autores.

Garcia et al. (2013), orienta sobre a importância de colocar-se no lugar daqueles que possuem alguma limitação, a fim de compreender o que se espera de um sistema com acessibilidade. Dessa maneira, é premente que desenvolvedores de sistemas online ou desktop ampliem a empatia pelas pessoas que passam por algumas limitações ou dificuldades para 
acessar esses sistemas, para, a partir daí, fazer uso de mecanismos técnicos com o intuito de promover melhorias de acessibilidade.

Os avanços tecnológicos e todas as vantagens que eles nos proporcionam são abordados por Nóbrega (2011) no sentido de levantar um questionamento sobre a validade desses avanços no contexto da inclusão. Quando um sistema não é acessível a todos, não só o conteúdo se torna limitado, mas também toda a interação com as demais pessoas que utilizam os sistemas e que possuam contato com o conteúdo. Assim, de certa forma, um sistema falho no tocante à acessibilidade é também excludente socialmente.

Nesse sentido, o recurso "legenda escrita" possibilita o acesso e a segurança para compreensão do conteúdo, tornando possível ao daltônico executar uma atividade e colaborar nas tarefas junto aos seus colegas de sala, sem passar por algum tipo de constrangimento ou mesmo manter-se calado por receio da reação dos demais alunos.

\section{Legenda ColorAdd}

As cores possuem uma adaptação própria para as pessoas com daltonismo por meio de ícones, conforme apresentado na Figura 5:

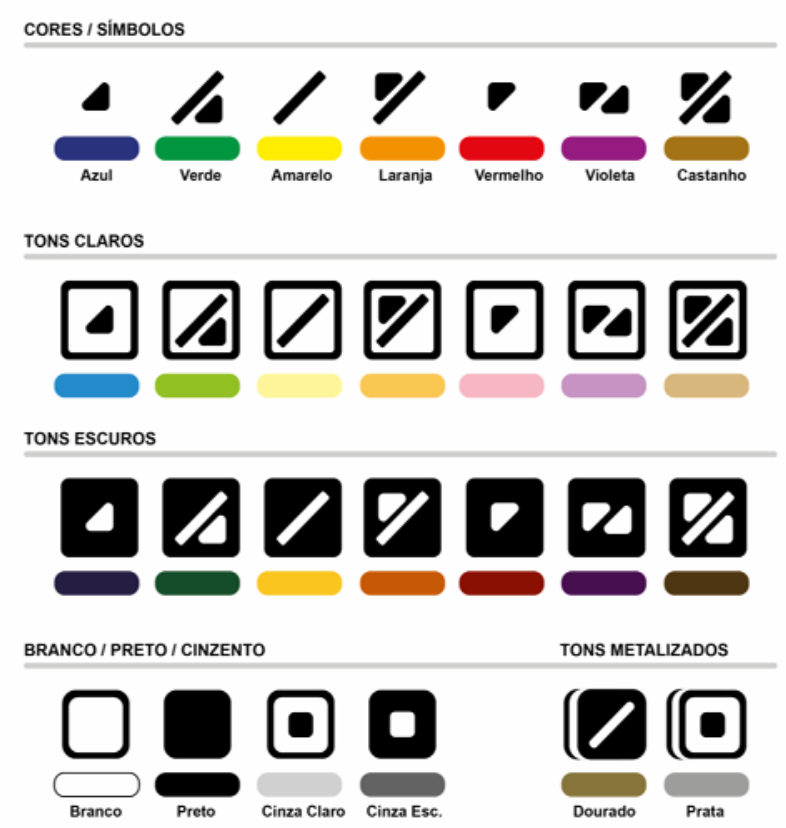

Fonte: Color identification system for colorblind people.

Esse código ColorADD é:

[...] um Sistema de Identificação das Cores premiado com a Medalha de Ouro da Comemoração da Declaração Universal dos Direitos do Homem. Uma ferramenta que procura garantir a plena integração de um público daltônico 
sempre que a Cor é fator determinante na comunicação e na aprendizagem. Estima-se que 350 milhões de indivíduos (cerca 10\% da população masculina mundial e $0,5 \%$ da população feminina) sejam daltônicos. (COLORADD, 2016, p.3).

Este modelo é vantajoso para quem já possui familiaridade com tais ícones. A forma como será utilizado segue o padrão do primeiro modelo, porém, o nome da cor será substituído pelo ícone, tendo como vantagem a economia de área de visualização ocupada. O Modelo ColorAdd pode ser visualizado na Figura 6 e 7

Figura 6 - Modelo do Protótipo "ColorAdd" - Ícone cor azul.

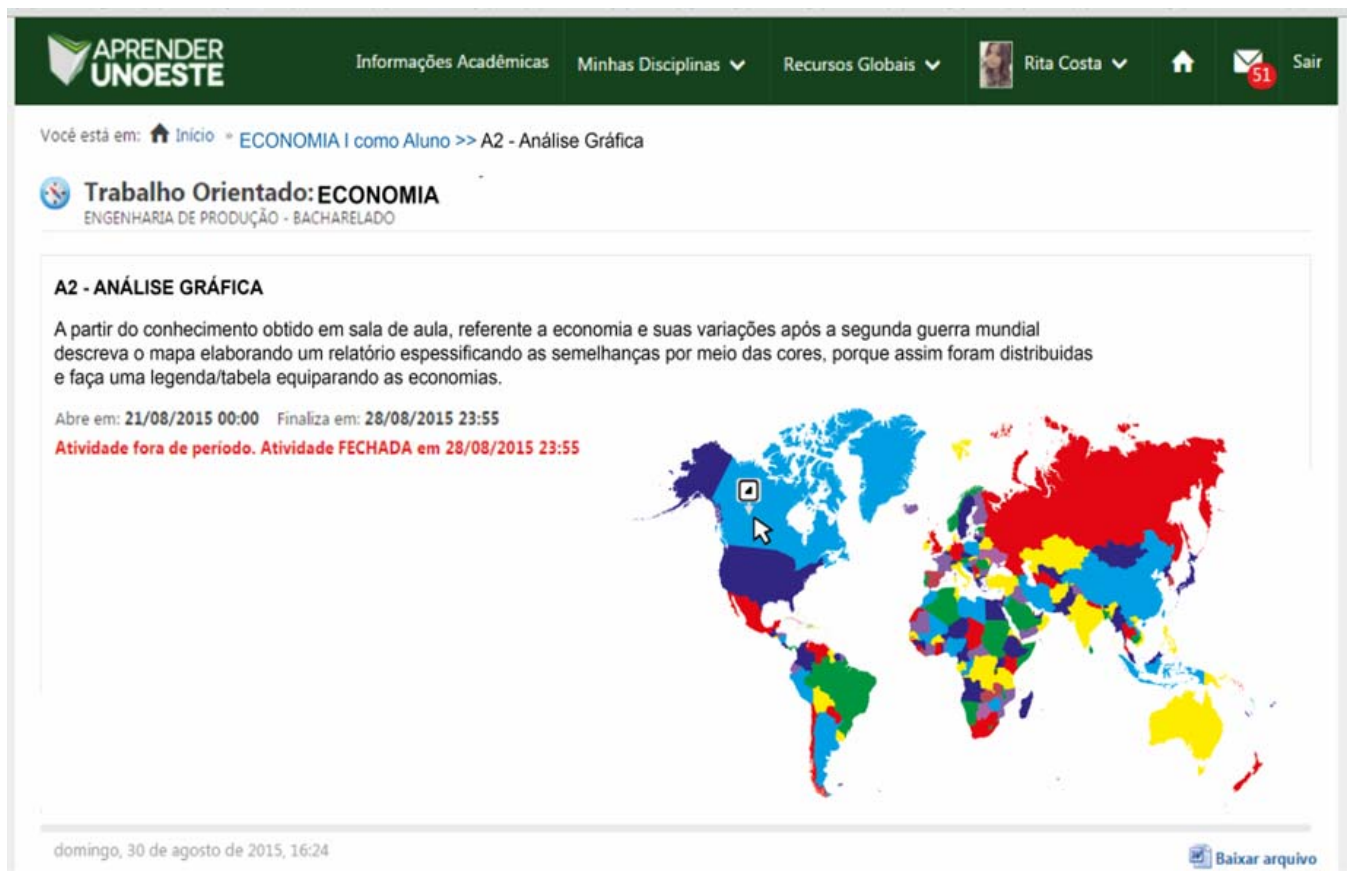

Fonte: Elaborado pelos autores. 


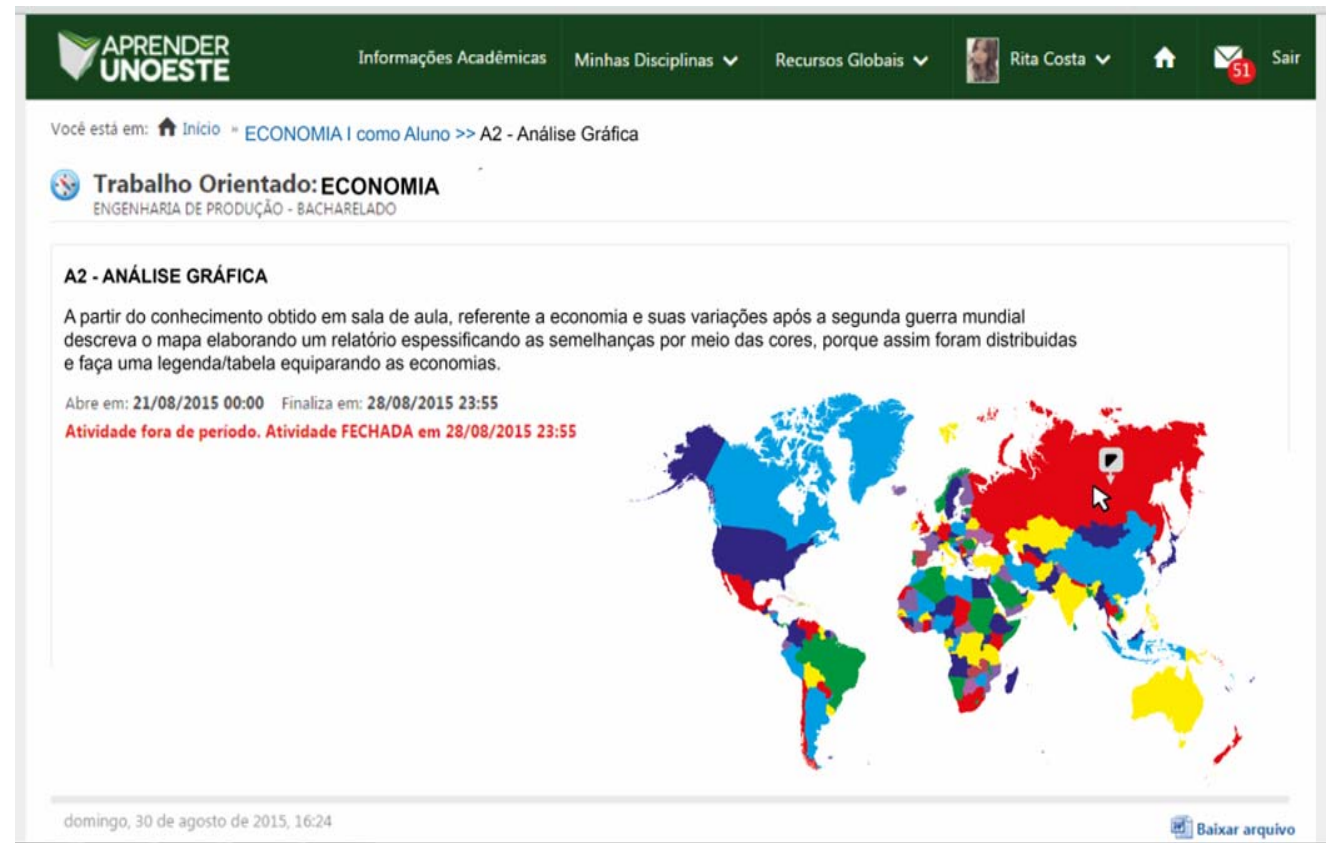

Fonte: Elaborado pelos autores.

Assim como as cores contribuem para a representação simbólica de algo, os ícones potencializam na compreensão quando as cores não são identificáveis por alguma razão. Nessa direção, Fontanella, Galon e Melo (2014, p. 1231), chamam a atenção para importância das cores na comunicação:

A cor é parte fundamental dos planos comunicacionais. A significação da cor pode abranger aspectos denotativos e conotativos. No sentido denotativo, é comum usar a cor como referência direta na qualificação de objetos (por exemplo, "o carro vermelho", "a camisa verde", etc.). Os significados conotativos referem-se às associações sugeridas pela cor (por exemplo, num sinal de trânsito a cor verde informa que o cruzamento está livre para passagem).

Dessa maneira, com o recurso "Legenda ColorAdd", por meio do qual os ícones auxiliam na visualização das cores, a familiaridade com o significado de cada símbolo, torna, além de eficiente, mais rápido a compreensão das cores, de uma forma que se compara a percepção de cores de um não daltônico, favorecendo a interação com o conteúdo e com outras pessoas. Nesse contexto, Santana, Almeida e Baranauskas (2008, p. 74) chamam a atenção para o seguinte pensamento: “No entanto, o papel da tecnologia como fator de integração entre pessoas, quando não consciente dos cuidados a se ter com relação à acessibilidade, pode ser distorcido, levando em certos casos, à separação entre pessoas sem ou com deficiência ou a exclusão desse segundo grupo."

Todavia, como ativar? Ambos possuem a mesma forma de ativação: na aba superior no Aprender haverá o ícone referente a acessibilidade para daltônicos, ao clicar no ícone aparecerá às opções: Legenda, ColorAdd e Conheça o ColorAdd. 
O ícone antes colorido passa a ficar cinza desta forma é possível constatar quando a ferramenta estará ativada ou desativada. As Figuras 7, 8, 9, 10, 11 e 12, indicam como seria a visualização dessa ferramenta no ambiente virtual - Aprender Unoeste.

Figura 8 - ícone de acessibilidade para daltônicos.

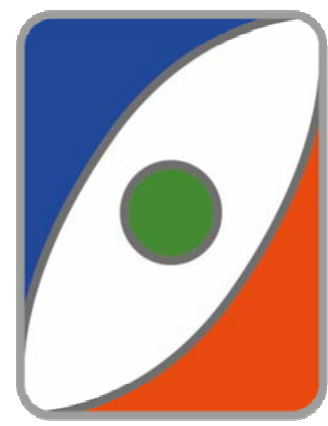

Fonte: Duarte, 2016

Figura 9 - Modelo do Ícone de ativação da ferramenta.

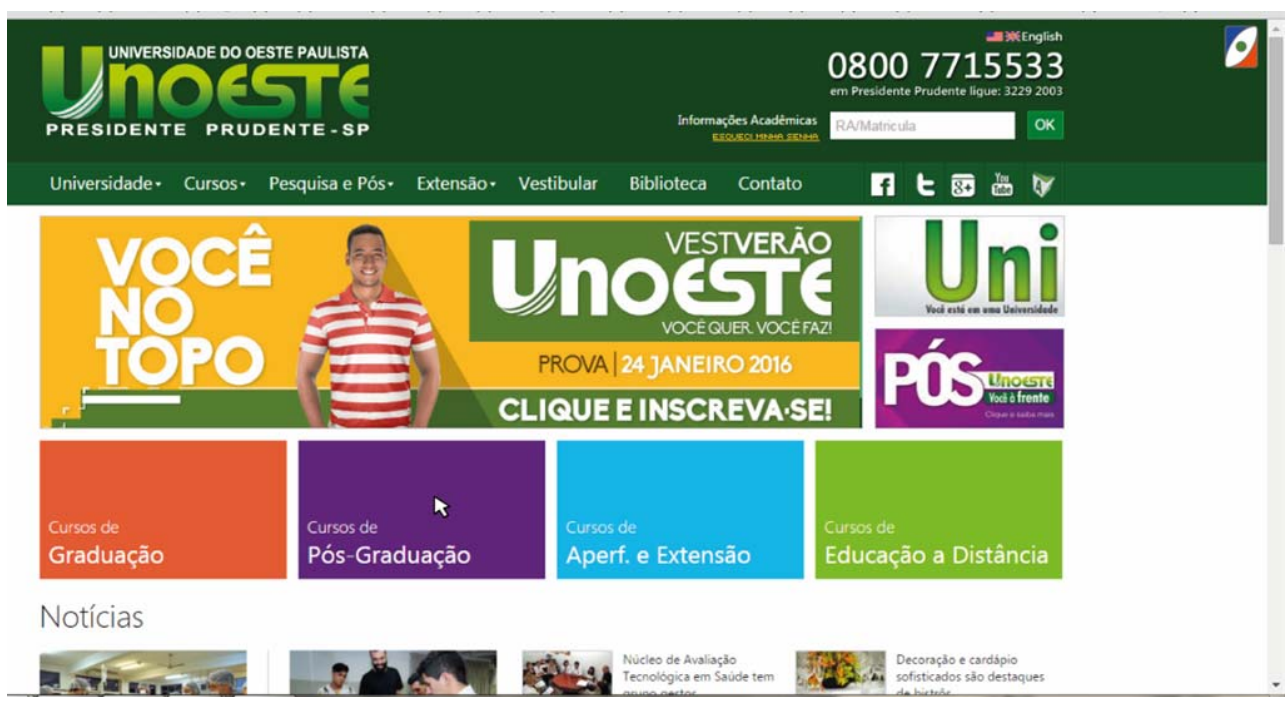

Fonte: Elaborado pelos autores. 
Figura 10 - Modelo do Ícone de ativação da ferramenta.

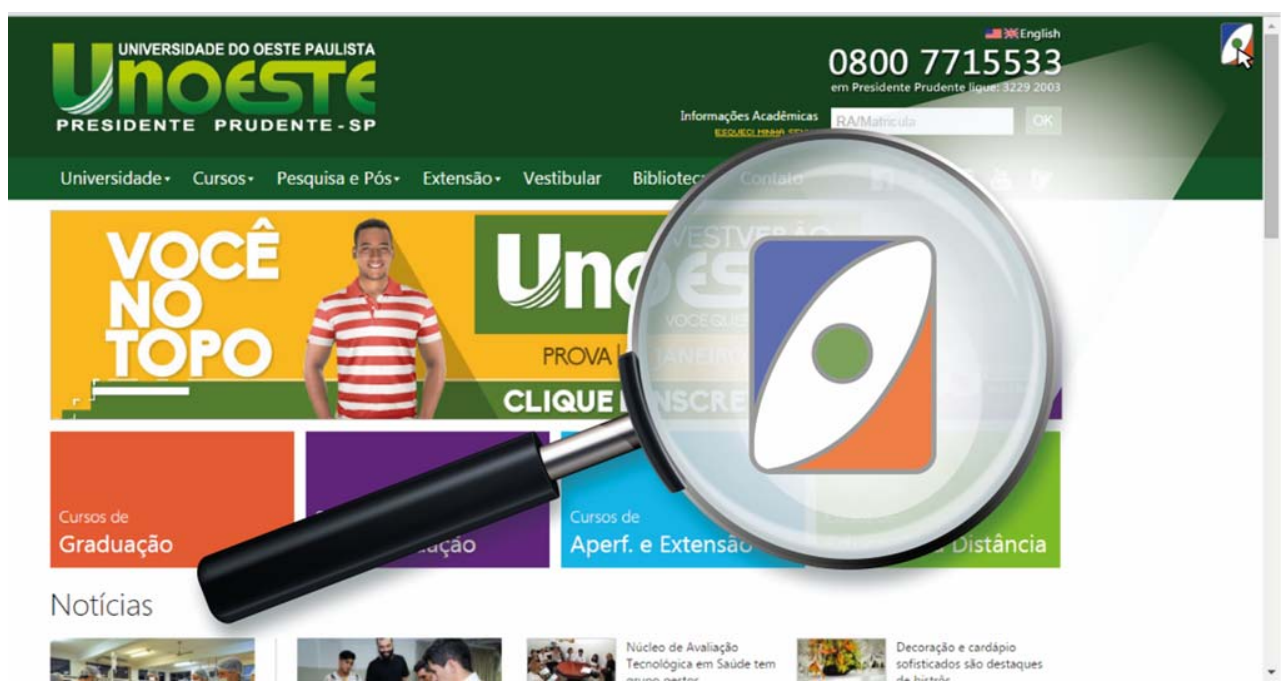

Fonte: Elaborado pelos autores.

Figura 11 - Opções ao clicar no ícone de acessibilidade.

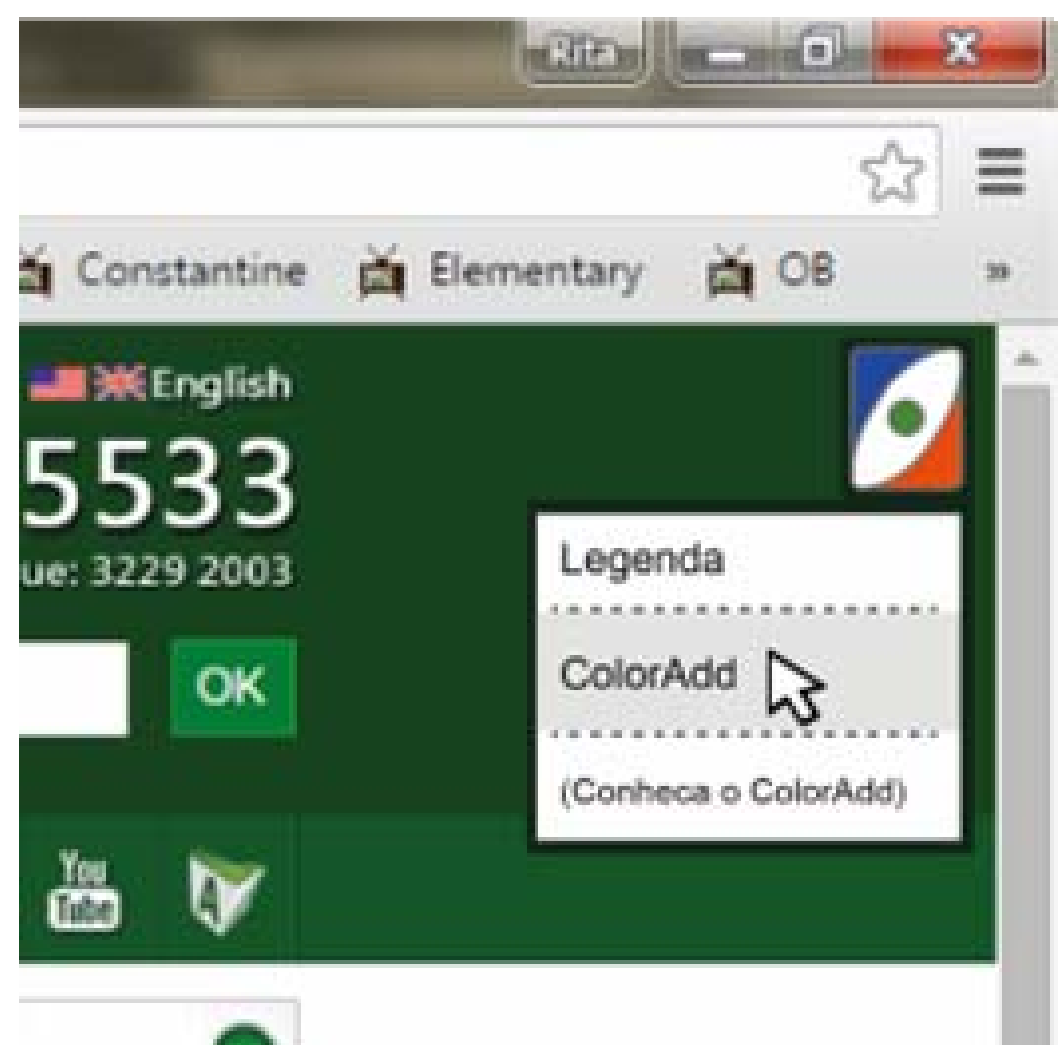

Fonte: Elaborado pelos autores. 


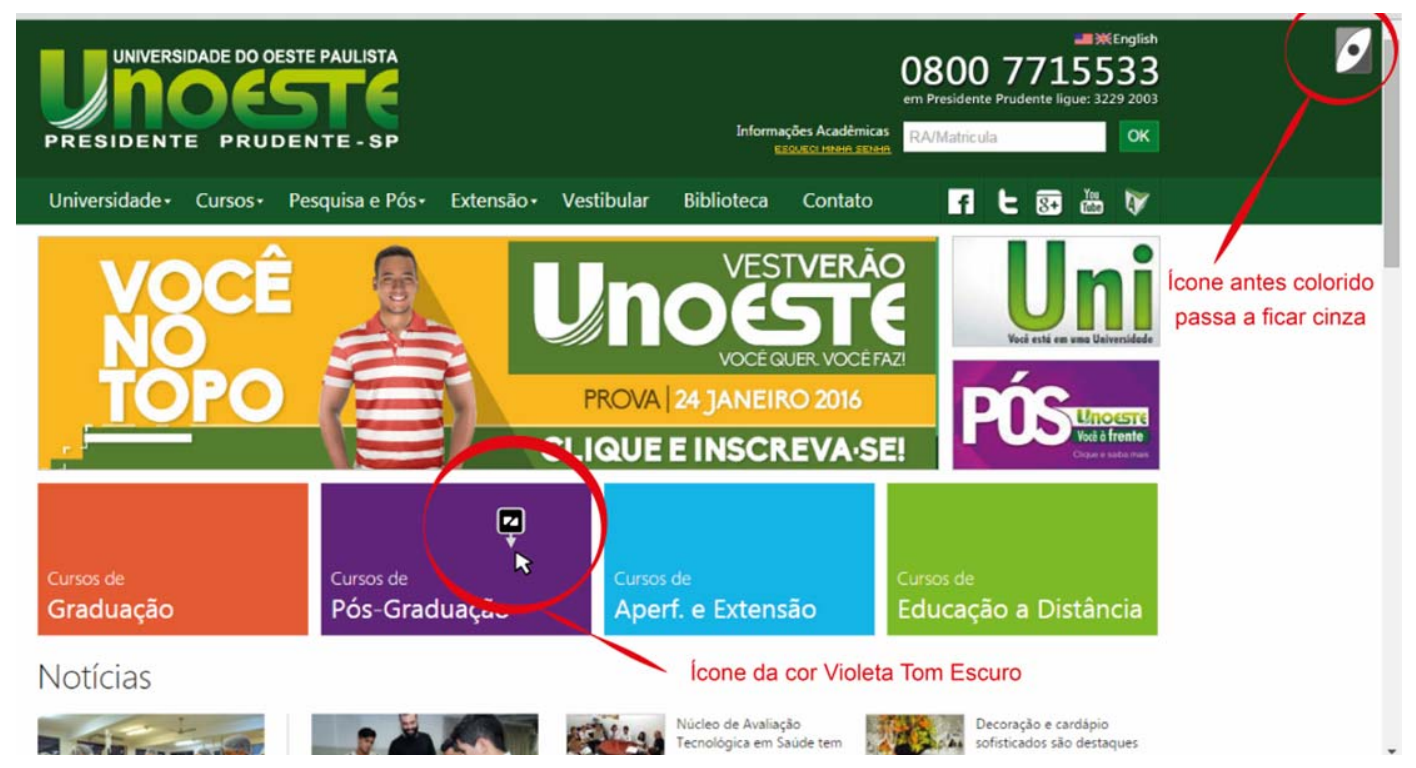

Fonte: Elaborado pelos autores.

Como mencionado, anteriormente, existem duas variáveis relevantes. Com relação à primeira variável, na qual a identificação de imagens/fotografias é prejudicada pelo grau de daltonismo do usuário, nesse caso, a separação e nomeação de cada cor pode não auxiliar na sua visualização, é preciso, nessas situações específicas, a recoloração da imagem.

Gomes e Ribeiro (2012) propõem uma técnica realizada para recolorir imagens em ambientes virtuais após tratá-las, manuseando-as ao nível de cada pixel que compõe a imagem (com o auxílio da linguagem de programação javascript). Gomes e Ribeiro (2012, p. 472), apresentam a solução da seguinte forma: "esta inovação possibilita a aplicação dos algoritmos de correcção de cor, às imagens, de forma directa, durante o carregamento da página nos browsers, sem recorrer a aplicações externas."

Convém salientar que, a recoloroção de imagem não é 100\% efetiva, já que existem diferentes tipos de daltonismo, e, em alguns casos, a recoloração pode acabar piorando a identificação da imagem.

No caso do protótipo apresentado neste artigo, ao ativar qualquer uma das opções: Legenda ou ColorAdd, será também ativado a recoloração que levará em consideração a forma mais comum de daltonismo, na qual o daltônico não consegue diferenciar a cor verde do vermelho.

A segunda variável diz respeito ao fato de algumas aplicações organizarem o Layout das páginas por meio de textos dentro de caixas, quadros ou tabelas. Dependendo do grau de daltonismo do usuário e das cores usadas, pode ser que a cor da escrita acabe se misturando com a cor aplicada ao fundo do texto. Nesse sentido, Nóbrega (2011, p. 23), considera que,

a utilização de uma cor no texto que contraste com a coloração do fundo auxilia os usuários com baixa visão, desde que a combinação de cores seja adequada às pessoas com daltonismo: não recomenda-se o uso da combinação vermelho/verde, vermelho/marrom ou azul/verde, por exemplo. 
Em relação aos impactos desta variável, em uma próxima etapa desta pesquisa será realizada uma orientação quanto ao uso adequado das cores, junto aos profissionais que trabalham com o Design de Interface da plataforma Apender Unoeste, orientando-os sobre esta questão e como proceder evitando as combinações citadas por Nóbrega (2011).

O protótipo aqui apresentado possui outras limitações que precisam ser aprofundadas em pesquisas futuras. Por exemplo, no caso da recoloração de imagens, poderiam ser trabalhadas subclassificações, uma vez que não há benefício $100 \%$ eficaz no tratamento de cores em imagens, devido ao fato de que cada daltônico as enxerga de maneiras diferentes, pois o grau de daltonismo depende da quantidade de cones e também de determinar quais deles possuem defeitos na retina.

Além disso, outros testes serão realizados com o intuito de validarmos a solução junto a usuários com daltonismo. Para isso, em uma próxima etapa deste estudo a solução projetada será efetivamente implementada no AVA Aprender Unoeste com o apoio da equipe de TI desta instituição. Na sequência serão convidados alguns estudantes da universidade que sejam daltônicos para realizarem o acesso ao AVA na versão adaptada para emitirem suas opiniões e nos auxiliarem na depuração da solução ilustrada no protótipo aqui apresentado. Somente após essa etapa de aplicação e testes serão sistematizados os resultados alcançados diante dos experimentos realizados com o público-alvo desta investigação.

Acredita-se assim que os avanços obtidos até o presente momento são essenciais para essa e outras instituições que almejam desenvolver ações, articulando ambientes virtuais nas modalidades presenciais e a distância se conscientizem da necessidade de repensar e buscar diferentes alternativas para que todos os seus usuários, sejam eles estudantes, docentes e equipe técnico-administrativa tenham condições de usufruir da melhor forma possível de todos os recursos tecnológicos que lhes forem ofertados.

Por fim, vale enfatizar que a implementação do protótipo, de forma efetiva no AVA, objeto desta análise, constituir-se-á o foco de uma pesquisa futura, ainda a ser realizada pelos pesquisadores envolvidos nesta investigação. O desenho do protótipo neste estudo limitou-se à descoberta de um caminho a ser seguido para adicionar um dispositivo no AVA Aprender Unoeste que possa torná-lo acessível a pessoas daltônicas. Esse objetivo foi atingido, conforme evidenciam as informações aqui apresentadas.

\section{Considerações finais}

Por meio desta pesquisa, concluiu-se que é possível a inclusão de recursos adicionais nos AVA, visando à melhoria de acesso de pessoas com daltonismo nesses espaços de aprendizagem. O protótipo construído evidencia que existem possibilidades para que tecnicamente o AVA de uma instituição que se diz "inclusiva", possa ser readequado, pensando no acolhimento, permanência e sucesso de estudantes daltônicos.

A legislação é clara quando se refere ao acesso a todos nos estabelecimentos de ensino de qualquer nível, etapa ou modalidade, públicos ou privados, e que estes devem proporcionar condições de acesso e utilização de todos os seus ambientes ou compartimentos para pessoas 
com deficiência ou com mobilidade reduzida, inclusive salas de aula, bibliotecas, auditórios, ginásios e instalações desportivas, laboratórios, áreas de lazer e sanitários.

Com o nítido avanço da tecnologia e das redes sociais interligadas pela internet ampliam-se também as possibilidades de educação inclusiva, tanto no acesso a ilimitadas informações, quanto na criação de práticas metodológicas alternativas. A partir dessa premissa, é possível criar oportunidades de acesso à educação para pessoas com necessidades que possam vir a comprometer a aprendizagem (ALMEIDA et al., 2011). Nesse sentido, se bem trabalhado, organizado e orientado aos responsáveis pela interface e customização do AVA utilizado na instituição é possível torná-lo acessível aos daltônicos, conforme evidenciado neste estudo.

O daltonismo é muitas vezes tratado como um assunto de pouca importância, devido à concepção de que pouco interfere no cotidiano dos daltônicos, porém é uma limitação para a execução de tarefas simples. Desse modo, entendemos que qualquer necessidade de acessibilidade em qualquer nível deva ser contemplada pelas várias esferas da sociedade, ou seja, há que se empregar esforços para garantir a acessibilidade e inclusão às pessoas que por alguma limitação, congênita ou adquirida, Ihes é vedado, considerando todas as modalidades de ensino.

\section{Referências}

ALMEIDA, A. C. F. de. et al. Acessibilidade para pessoas com deficiência visual no Moodle. Linhas Críticas, Brasília, DF, v. 17, n. 33, p. 327-348, dez. 2011. Disponível em: <http://periodicos.unb.br/index.php/linhascriticas/article/view/5697/4709>. Acesso em: 15 abr. 2015.

BEHAR, P. A. et al. A importância da acessibilidade digital na construção de objetos de aprendizagem. RENOTE, Rio Grande do Sul, v. 6, n. 1, 2008. Disponível em: <http://seer.ufrgs.br/index. php/renote/article/view/14459/8381>. Acesso em: 10 mai. 2015.

BESSANI, P. B. S. et al. Usabilidade e acessibilidade no desenvolvimento de interfaces para ambientes de educação à distância. In. RENOTE, v. 8, n. 1, 2010. Disponível em: <http://seer.ufrgs.br/renote/article/view/15180>. Acesso em: 10 mai. 2015.

BRASIL. Decreto n. 5.296, de 02 de dezembro de 2004. Regulamenta as Leis $\mathrm{n}^{\text {os }} 10.048$, de 8 de novembro de 2000, que dá prioridade de atendimento às pessoas que especifica, e 10.098, de 19 de dezembro de 2000, que estabelece normas gerais e critérios básicos para a promoção da acessibilidade das pessoas portadoras de deficiência ou com mobilidade reduzida, e dá outras providências. Diário Oficial da União, Brasília, DF, 03 dez. 2004. Disponível em: <http://www.planalto.gov.br/ccivil_03/_ato2004-2006/2004/decreto/d5296.htm>. Acesso em: 13 dez. 2015.

Decreto no 5.622, de 19 de dezembro de 2005. Regulamenta o art. 80 da Lei no 9.394, de 20 de dezembro de 1996, que estabelece as diretrizes e bases da educação nacional. Diário Oficial da União, Brasília, DF, 20 dez., 2005. Disponível em:

<http://www2.camara.leg.br/legin/fed/decret/2005/decreto-5622-19-dezembro-2005-539654normaatualizada-pe.pdf>. Acesso em: 10 abr. 2015.

Decreto no 6.949, de 25 de agosto de 2009. Promulga a Convenção Internacional sobre os Direitos das Pessoas com Deficiência e seu Protocolo Facultativo, assinados em Nova York, em 30 de março de 2007. Diário Oficial da União, Brasília, DF, 26 ago. 2009. Disponível em: <http://www.planalto.gov.br/ccivil_03/_ato2007-2010/2009/decreto/d6949.htm>. Acesso em: 10 abr. 2015. 
Ministério da Educação Instituto Nacional de Estudos e Pesquisas Educacionais Anísio Teixeira. Notas Estatísticas Censo da Educação Superior, 2014. Disponível em: <http://download.inep.gov.br/educacao_superior/censo_superior/documentos/2015/notas_sob re_o_censo_da_educacao_superior_2014̄.pdf>. Acesso èm: 10 dez. 2015.

DUARTE, A. Acessibilidade para Daltônicos na Web. Disponível em:

http://www.daltonicos.com.br/daltonico/index.html. Acesso em: 18 abr. 2016.

GARCIA, F. E. A. S. et al. Aplicação da Interação Humano-Computador no Desenvolvimento de Interfaces Gráficas Destinadas a Daltônicos. Revista E-f@tec, Garça, v. 3, n. 2, 2013.

Disponível em: <http://www.fatecgarca.edu.br/revista/Volume3/artigos_vol3/Artigo_19.pdf>. Acesso em: 23 jan. 2016.

GOMES, A; RIBEIRO, M.M.G. Recoloração de web conteúdos para daltónicos: recoloração de imagens. In: Conferência Internacional em Design e Artes Gráficas, 2, 2012, Tomar. Desafios conceptuais para o design e a produção gráfica: livro de actas. Lisboa: ISEC. p. 470-473. Disponível em:

<http://gcd.isec.universitas.pt/anexos/miolo_\%20Livro_\%20Actas_CIDAG2012_Julho\%202013 .pdf>. Acesso em: 10 abr. 2015.

COLORADD: Color identification system. Disponível em:

<http://www.coloradd.net/imgs/ColorADD-Sobre-Nos_0315.pdf>. Acesso em: 19 jan. 2016.

COLOR IDENTIFICATION SYSTEM FOR COLORBLIND PEOPLE. Disponível em:

<http://www.coloradd.net/>. Acesso em: 19 jan. 2016.

COLOUR BLIND AWARENESS. 2014. Disponível em: <http://www.colourblindawareness.org/>. Acesso em: 19 jan. 2016.

LÉVY, P. Cibercultura. São Paulo: Editora 34, 2009.

MELO, D. G.; GALON, J. E. V.; FONTANELLA, B. J. B. Os "daltônicos" e suas dificuldades: condição negligenciada no Brasil? Physis: Revista de Saúde Coletiva, v. 24, n. 4, p. 1229-1253, dez. 2014. Disponível em: <http://www. scielosp.org/scielo. php?script=sci arttext\&pid=S0103$73312014000401229 \&$ lng=pt\&nrm=iso $>$. Acesso em: 10 jan. 2016.

NÓBREGA, G. C. Acessibilidade aos conteúdos visuais em ambientes virtuais de aprendizagem. Revista Brasileira de Tradução Visual, Recife, PE, v. 9, n. 9, 2011. Disponível em: <http://rbtv.associadosdainclusao.com.br/index. php/principal/article/viewFile/114/184>. Acesso em: 15 jan. 2016.

PRATES, R. O.; BARBOSA, S. D. J. Avaliação de interfaces de usuário: conceitos e métodos. Disponível em: <http://homepages.dcc.ufmg.br/ rprates/ge_vis/cap6_vfinal.pdf>. Acesso em: 10 jan. 2016.

SASSAKI, R. Inclusão: o paradigma do século 21. Revista Inclusão, vol. 1, n. 1, p. 19-23, out. 2005. Disponível em: <http://portal.mec.gov.br/seesp/arquivos/pdf/revistainclusaol. pdf>. Acesso em: 10 jan. 2016.

SANTANA, V. F.; ALMEIDA, L. D. A.; BARANAUSKAS, M. C. C. Aprendendo sobre acessibilidade e construção de websites para todos. Revista Brasileira de Informática na Educação, v. 16, n. 03, dez. 2008. Disponível em: <http://www.br-ie.org/pub/index.php/rbie/article/view/45/39>. Acesso em: 14 dez. 2015.

SONZA, A. P.; CONFORTO, D.; SANTAROSA, L. Acessibilidade nos portais da educação profissional e tecnológica do Ministério da Educação. In: Revista Brasileira de Educação Profissional e Tecnológica, Brasília, v. 1, n. 1, p. 131-146, jun. 2008. Disponível em: <http://www2.ifrn.edu.br/ojs/index.php/RBEPT/article/view/2874>. Acesso em: 14 dez. 2015.

TORRES, E. F.; MAZZONI, A. A.; ALVES, J. B. da M. A acessibilidade à informação no espaço digital. Ciência da Informação, Brasília, v. 31, n. 3, p. 83-91, set. 2002. Disponível em: 
<http://www.scielo.br/scielo.php?script=sci_arttext\&pid=S0100-

19652002000300009\&lng=en\&nrm=iso>. Acesso em: 19 jan. 2016.

Recebido em agosto de 2016

Aprovado para publicação em agoto de 2017

\section{Rita de Cassia Miranda da Costa}

Programa de Pós-Graduação em Educação - Universidade do Oeste Paulista - UNOESTE, Presidente Prudente/SP, Brasil, rita.cmc92@gmail.com

\section{Adriana Aparecida de Lima}

Programa de Pós-Graduação em Educação - Universidade Nove de Julho - UNINOVE, São Paulo/SP, Brasil, atercariol@gmail.com

\section{Fernanda Sutkus de Oliveira Mello}

Docente do Programa de Graduação em Sistemas para Internet, Publicidade, Jornalismo e Design Gráfico Universidade do Oeste Paulista - UNOESTE, Presidente Prudente/SP, Brasil, fernanda_mello@unoeste.br

\section{Sidinei de Oliveira Sousa}

Docente do Programa de Pós-Graduação em Educação - Universidade do Oeste Paulista - UNOESTE, Presidente Prudente/SP, Brasil, sidinei@unoeste.br

\section{Elisangela Aparecida Bulla I keshoji}

Professora do Ensino Básico, Técnico e Tecnológico - Instituto Federal de Educação, Ciência e Tecnologia de São Paulo/Câmpus Birigui - IFSP, Birigui/SP, Brasil, elisangela.bulla@gmail.com 